\title{
PERANAN GURU DALAM MENCIPTAKAN PEMBELAJARAN YANG KREATIF
}

\author{
Mitro \\ Institut Agama Hindu Negeri Tampung Penyang Palangkaraya \\ bawiayahfda@gmail.com
}

Riwayat Jurnal

Artikel diterima

Artikel direvisi

Artikel disetujui

\section{Abstrak}

Dalam interaksi edukatif, guru tidak cukup hanya mengetahui bahan ilmu pengetahuan yang akan dijabarkan dan disajikan kepada siswa, tetapi juga harus mengetahui filosofis dan didaktisnya, sehingga mampu memberikan motivasi di dalam kegiatan belajar mengajar. Proses belajar mengajar, guru memegang peranan penting karena bertindak sebagai pengelola dan pelaksana interaksi belajar mengajar. Guru bertindak sebagai perencana, membimbing dan mengarahkan dalam memberi motivasi, agar terjadi proses interaksi yang memungkinkan terjadinya proses belajar dengan baik. Dalam melaksanakan tugasnya sebagai penyaji pelajaran khususnya di depan kelas, guru tidak hanya dituntut menyusun perencanaan pengajaran dan mentransfer pengetahuan atau isi pelajaran yang disajikan kepada para siswanya, tetapi guru juga harus mentransfer kecakapan karsa dan kecakapan rasa yang terkandung dalam materi pelajaran yang disajikan.

Kata Kunci : Peranan, Guru, Pembelajaran Kreatif

\section{PENDAHULUAN}

Pembangunan nasional sekarang ini sedang giat dilaksanakan oleh masyarakat Indonesia, yang meliputi semua bidang kehidupan. Kegiatan pembangunan dimaksud meliputi berbagai bidang seperti politik, sosial budaya, ekonomi, pertanian dan pendidikan, yang kesemuanya bertujuan untuk mewujudkan masyarakat adil dan makmur yang merata baik material maupun spiritual berdasarkan Pancasila dan Undang-Undang Dasar 1945.

Salah satu diantara bidang-bidang pembangunan tersebut di atas, yang tidak kalah pentingnya adalah pembangunan bidang pendidikan. Pendidikan memegang peranan penting dan diperlukan oleh setiap individu karena 
melalui proses pendidikan individu akan mampu mengikuti gerak pembangunan yang sedang berlangsung sekarang maupun masa yang akan datang. Hal ini sebagaimana telah diatur pelaksanaannya untuk mencapai Tujuan Pendidikan Nasional, sebagai berikut :

Pendidikan nasional berfungsi mengembangkan kemampuan dan membentuk watak serta peradapan bangsa yang bermartabat dalam rangka mencerdaskan kehidupan bangsa, bertujuan untuk mengembangkan potensi peserta didik agar menjadi manusia yang beriman dan bertaqwa kepada Tuhan Yang maha Esa, berahklak mulia, sehat berilmu, cakap, kreatif, mandiri dan menjadi warga negara yang demokratis serta bertanggung jawab (Undang-Undang Sistem Pendidikan Nasional, No.2 pasal 3 tahun 2003).

Untuk mencapai tujuan pendidikan nasional tersebut, pemerintah menggalakan pendidikan dan pengajaran disemua sektor kehidupan masyarakat. Sardiman (1996:12) mengemukakan bahwa "pendidikan adalah salah satu usaha yang bersifat sadar tujuan yang dengan sistematis terarah pada perubahan tingkah laku menuju kedewasaan anak didik".
Berdasarkan pendapat tersebut, pengajaran merupakan proses yang berfungsi mengarahkan siswa di dalam kehidupannya sehari-hari, sesuai dengan tugas dan kewajiban serta hak yang dimilikinya. Hal ini mencakup kebutuhan hidup baik individu maupun sebagai masyarakat dan juga sebagai makhluk Tuhan. Jadi manusia hidup dan berkembang adalah manusia yang selalu berubah dan perubahan itu merupakan hasil belajar. Namun tidak semua hasil belajar itu berlangsung secara sadar dan terarah. Bahkan ada kecenderungan bahwa perubahan-perubahan yang tidak disadari dan tidak direncanakan itu lebih banyak memberi kemungkinan perubahan tingkah laku yang berada di luar tujuan. Sebab itu perlu diarahkan secara sistematis, dalam memberi bekal sesuatu yang berguna kepada siswa dengan mengelola interaksi edukatif.

Muhibbin Syah (1996:182)
mengatakan "mengajar
mengandung konotasi membimbing dan
membantu untuk memudahkan siswa
dalam menjalani proses perubahannya
sendiri, yaitu proses belajar untuk meraih
kecakapan cipta, rasa, dan karsa yang
menyeluruh dan utuh". Sejalan dengan


pendapat di atas, maka yang dimaksud dengan guru yang profesional adalah guru yang memiliki prinsip sebagai berikut.

1. Memiliki bakat, minat, panggilan jiwa dan idealisme;

2. Memiliki komitmen untuk meningkatkan mutu pendidikan, keimanan, ketaqwaan, dan akhlak mulia;

3. Memiliki kualifikasi akademik dan latar belakang pendidikan sesuai dengan bidang tugas;

4. Memiliki kompetensi yang diperlukan sesuai dengan bidang tugas;

5. Memiliki tanggung jawab atas pelaksanaan tugas keprofesionalan;

6. Memperoleh penghasilan yang ditentukan sesuai dengan prestasi kerja;

7. Memiliki kesempatan untuk mengembangkan

keprofesionalan secara berkelanjutan dengan belajar sepanjang hayat;

8. Memiliki jaminan perlindungan hukum dalam melaksanakan tugas keprofesionalan,

9. Memiliki organisasi profesi yang mempunyai kewajiban mengatur hal-hal yang berkaitan dengan tugas keprofesionalan guru (UU Guru dan Dosen Nomor 14 Tahun 2005).

Untuk dapat menjalankan tugas dan tanggung jawab tersebut, guru berkewajiban merealisasikan segenap upaya yang mengarah pada pengertian membantu dan membimbing siswa dalam melapangkan jalan menuju perubahan positif seluruh ranah kejiwaannya. Kegiatan nyata yang paling utama dalam memberi bantuan dan bimbingan tersebut adalah melaksanakan proses mengajar.

Berdasarkan uraian tersebut, maka rangkaian kegiatan yang berhubungan dengan proses pembelajaran ini perlu mendapat perhatian serius dari pihakpihak yang terkait, terutama guru sebagai pelaksana kegiatan tersebut.

\section{PEMBAHASAN}

Peranan berasal dari kata dasar "peranan” jika ditinjau dari arti kata yang terdapat pada Kamus Umum Bahasa Indonesia karya Poewadarminta (1984:753) mempunyai arti sebagai berikut : "1. Pemain Sandiwara atau Tukang Lawak; 2. Balok yang menyambung tiang rumah sebelah atas tempat kasau-kasau bertumpu". Kata "peran" jika ditambah akhiran "an" menurut Poerwadarminta (1984:753) menjadi kata mempunyai arti "sesuatu yang menjadi bagian atau yang memegang pimpinan yang terutama". Kata peranan dalam konteks penelitian merupakan salah satu bagian komponen dari proses pengajaran dan pengadaan 
guru sebagai bagian utama/ujung tombak keberhasilan dibidang pendidikan diharapkan mampu berkreativitas untuk menciptakan dan membuat suasana pembelajaran yang kreatif dan menyenangkan.

Pengertian “peranan” mengarah pada maksud daru Undang-Undang Republik Indonesia, Nomor 14 Tahun 2005 tentang Guru dan Dosen, pada BAB II, tentang Kedudukan, Fungsi dan Tujuan pasal 6 yang berbunyi :

Kedudukan guru dan dosen sebagai tenaga profesional bertujuan untuk melaksanakan sistem pendidikan nasional dan mewujudkan tujuan pendidikan nasional, yaitu berkembangnya potensi peserta didik agar menjadi manusia yang beriman dan bertaqwa kepada Tuhan Yang Maha Esa, berakhlak mulia, sehat, berilmu, cakap, kreatif, mandiri serta menjadi warga Negara yang demokratis dan tanggung jawab.

Sehubungan dengan kedudukan guru menurut amanat undang-undang, maka peranan guru baik itu berupa kreativitas, kemampuan dan motivasi guru untuk mewujudkan tujuan pendidikan nasional ataupun sistem pendidikan nasional sangatlah memegang peranan penting.
Jadi pengertian "peranan" disini adalah menyangkut segala potensi, kemampuan, kreativitas dan motivasi guru untuk memberdayakan secara optimal guna mengimplementasikan sistem pendidikan nasional dan juga mewujudkan tujuan pendidikan nasional, sesuai dengan yang diamanatkan oleh undang-undang.

Guru sebuah profesi yang sangat mulia bagi bangsa dan negara, dimana guru mempunyai tugas untuk mendidik dan mengajar anak didiknya dengan penuh kesabaran dan tanggung jawab, mentransfer ilmu pengetahuan yang dia miliki kepada anak didiknya, sehingga merubah dan juga menambah wawasan anak didiknya menjadi kearah yang lebih berilmu, dari yang tidak tahu menjadi tahu, dari yang tidak bisa menjadi bisa. Hasil kerja guru juga dapat dilihat dari perubahan perilaku hidup anak didiknya menjadi lebih dewasa dan bersikap penuh pertimbangan dalam menetukan pilihan untuk segala hal.

Ada bermacam-macam pandangan mengenai arti dari guru, dalam Kamus Umum Bahasa Indonesia karya Poerwadarminta (1984:335), guru diartikan sebagai pekerjaan/profesi, yaitu 
"orang yang kerjanya mengajar".

Sedangkan pandangan-pandangan lain tentang arti guru menurut beberapa kalangan yang terangkum dalam buku yang berjudul Masalah-masalah Ilmu Keguruan karya Roestiyah, N.K (1986:176) menyatakan arti guru sebagai berikut :

a. Menurut pandangan tradisional yaitu yang selama ini diterima adalah : guru adalah seorang yang berdiri di depan kelas untuk menyampaikan ilmu pengetahuan.

b. Teacher is a person who causes a person to know or be able to do something or gives a person knowledge Or skill, dengan terjemahan sebagai berikut : guru adalah seorang yang menyebabkan orang lain mengetahui atau mampu melaksanakan sesuatu atau yang memberikan pengetahuan dan keterampilan kepada orang lain;

c. Menurut N. E. A. (National Education Association), persatuan guru-guru Amerika Serikat mengartikan guru sebagai berikut "guru diartikan sebagai semua petugas yang langsung terlibat dalam tugastugas kependidikan.

Tugas guru pada umumnya adalah mewariskan ilmu pengetahuan dan berbagai keterampilan kepada anak didiknya, tentunya hal-hal yang akan ditransfer atau diwariskan itu harus sesuai dengan ukuran-ukuran yang telah ditentukan oleh kurikulum, masyarakat dan merupakan gambaran tentang keadaan nasional, ekonomi dan politik pada masyarakat yang bersangkutan.

Mengingat begitu berat dan mulianya tugas yang diembankan oleh guru, hendaknya profesi guru harus memenuhi ukuran kemampuan yang diperlukan untuk melaksanakan tugasnya, yang diharapkan peserta didik dapat mencapai ukuran pendidikan yang optimal.

Ajaran Agama Hindu dari dahulu kala sudah mengenal dan mempraktikkan suatu sistem pendidikan. Hal ini dapat kita telusuri pada susastra-susastra Hindu kuno yang diantaranya adalah pada jaman "Upanisad". Upanisad adalah salah satu kitab yang disucikan oleh umat Hindu. Kitab Upanisad merupakan dari kitab Sruti yang merupakan sumber utama sastra Hindu, karena Sruti merupakan wahyu dari Hyang Widhi Wasa. Kitab Upanisad merupakan awal atau permulaan sejarah berkembangnya alam pikiran Agama Hindu, dimana dijaman Upanisad ini banyak memberikan 
sumbangan pemikiran terhadap perkembangan filsafat Agama Hindu.

Kata Upanisad menurut I Gede Rudia Adiputra, dkk dalam bukunya yang berjudul yang berjudul Tattwa Darsana (1990:01) diartikan : Upanisad berasal dari akar kata "Upa", yang artinya dekat, kemudian "Ni" yang artinya di bawah "Sad" yang artinya duduk. Dengan demikian arti dari kata Upanisad adalah “duduk di bawah dekat" (Dang Acarya) atau guru.

Upanisad memuat tentang pokokpokok "ajaran guru sejati”, dalam proses pembelajarannya, bagi yang belajar (sisya) duduk bersimpuh didekat kaki Dang Acarya (guru). Dengan duduk dekat kaki guru itu siswa akan dapat mendengar ajaran yang disampaikan oleh guru. Sebelum jaman Upanisadpun Agama Hindu sudah mengenal tentang sistem pembelajaran, pada saat jaman Brahmana, ketika terjadi regenerasi bagi Brahmana maka proses pembelajaran pun dilakukan dengan cara-cara yang ditetapkan oleh aturan-aturan Weda. Begitu pula jaman setelah Upanisad, banyak dicontohkan dan diriwayatkan dalam Itihasa yaitu pada kitab Mahabharata dan Ramayana.
Model-model pembelajaran Hindu kuno sangat efektif digunakan, hingga sekarang proses pendidikan ala Itihasa masih banyak dijumpai di Indonesia, hanya berbeda unsur penunjang dan sarana belajar. Sistem belajar itu dikenal dengan istilah Ashram. Dan sekarang dikenal dengan istilah Asrama atau ada juga yang menyatakan pesantren. Guru dalam persfektif Agama hindu termasuk dalam konsep ajaran Tata Susila yang tergolong dalam keadaan Catur Guru/Guru Bhakti yang artinya diungkapkan oleh Ida Bagus Rai Wardana, S.H dalam buku pelajaran Agama Hindu (1997:95) dikatakan "Kata Catur Guru/Guru Bhakti dalam ajaran susila atau etika Hindu diartikan empat guru yang patut dihormati”. Empat guru yang patut dihormati tersebut adalah :

\section{a. Guru Rupaka (Guru Reka)}

Guru Rupaka yang sering disebut Guru Reka adalah orang tua kita yaitu bapak dan ibu kandung kita, yang melahirkan, memelihara, merawat, membesarkan dan mengajar berbagai ilmu pengetahuan selama di rumah.

Ibu yang mengandung merupakan guru yang pertama, karena beliau telah mendidik anaknya sedari dalam 
kandungan melalui berbagai pantangan yang tidak boleh dilakukan. Ibu menjaga anak yang dikandungnya serta mendidiknya dengan cara melakukan disiplin dengan pantangan, baik itu marah, mencuri, berkata kasar dan lain sebagainya agar anaknya nanti lahir dan besar menjadi orang baik dan berguna. Kemudian setelah lahir dipelihara oleh kedua orang tuanya dalam suka dan duka, hingga kelak menjadi besar dan berguna.

Pengorbanan, jasa dan tanggung jawab mereka sangat besar terhadap keberadaan baik buruknya kita. Kita sebagai anaknya tidak boleh menentang atau tidak mengakuinya. Dalam sastra (Slokantara 26) diberikan petunjuk dalam menuntun diri kita untuk beretika dengan tema tidak membalas budi. "Ekaksara pradataram dataram nanumanyata cwinnayomau prasuta tu candela hayati thijayate”. Artinya : “orang yang tidak mau mengakui guru, orang yang telah memberikan pelajaran padanya walaupun sedikit saja, ia nanti akan lahir mula-mula sebagai anjing dan kemudian sebagai orang candela".

Dari uraian sastra Slokantara diatas tadi kita dituntut untuk selalu menghormati guru, sebab dari guru itulah kita mendapat pengetahuan, yang patut untuk dijadikan pedoman dalam mengarungi hidup ini.

b. Guru Pengajian (Guru di Sekolah)

Guru pengajian adalah guru di sekolah, guru pengajian banyak memberikan kita ilmu pengetahuan yang berbagai macam jenisnya dan sangat berguna dalam kehidupan manusia. Ilmu pengetahuan yang diberikan oleh guru pengajian adalah ilmu alam, kesehatan, social, politik, keamanan, ekonomi dan lain sebagainya. Umat Hindu tidak dibenarkan untuk mengingkari atau menentang guru, apalagi menghina serta menyakitinya. Perbuatan yang menentang guru dalam ajaran Hindu disebut alpaca guru pengajian, hal itu jika dilakukan akan membuahkan dosa, pengabdian kepada guru adalah sangat utama. Pustaka Bhagawadgita IV sloka 33 menyebutkan :

Sreyan dravymayad yadnya, Jnanayajnah paramtapa

Sarvam karma khilam partha Jnane parisamapyate

Artinya :

Persembahan kurban berupa pengetahuan adalah lebih agung sifatnya dari pada korban benda yang berupa apapun juga, $\mathrm{O}$ Arjuna. Sebab segala pekerjaan dengan tak terkecualinya memuncak didalam kebijaksanaan. 
Pemberian pengetahuan oleh guru didasari dengan budhi sehingga sulit untuk dilupakan karena meresap kepada budhi kita, begitu besar guru memberikan segala pengetahuan yang telah kita terima, maka ajaran Hindu menekankan untuk selalu menghormati dan berbhakti kepada guru.

\section{c. Guru Wisesa (Pemerintah)}

Guru Wisesa adalah pemerintah, pada jaman dahulu pemimpin pemerintahan adalah seorang raja, disaat sekarang sejak proklamasi, maka pemimpin negara kita adalah seorang presiden beserta para aparat yang membantu melaksanakan roda pemerintahan.

Pemerintah disebut guru wisesa karema pemerintah yang melindungi, memberikan rasa aman, tenteram dan damai bagi segenap bangsa dan warga negara Indonesia. Kepentingan bangsa dan negara menjadi prioritas atau lebih tinggi kedudukannya dibandingkan kepentingan pribadi.

Pengabdian kepada Negara adalah dengan cara taat kepada aturan yang telah ditetapkan serta memenuhi/melaksanakan hak dan kewajiban sebagai warga negara (Dharma Negara) guna menciptakan suasana yang aman, damai, tenteram dan sejahtera yang didambakan oleh setiap insan.

\section{d. Guru Swadhyaya (Guru Sejati/Hyang Widhi Wasa) \\ Guru Swadhyaya adalah suatu} istilah bagi umat Hindu untuk menyebut dari Tuhan Yang Maha Esa yang diyakini keberadaan-Nya, serta sebagai pencipta dari segala yang ada di semesta ala mini. Hyang Widhi pula yang memelihara dan juga mengembalikan ciptaan-Nya kepada asalnya.

Untuk menghormati guru swadhyaya maka umat Hindu wajib untuk belajar sastra agama, menjauhi laranganNya dan melaksanakan sabda-sabda-Nya untuk menjamin kehidupan kita agar bahagia di dunia dan akhirat. Selain itu kewajiban kita adalah dengan membiasakan diri untuk berdoa, bersembahyang dan menerapkan ajaran suci-Nya yang terdapat dalam ajaran Tri Kerangka Agama Hindu yang terdiri dari Tattwa, Susila dan Upacara.

$$
\text { Pendapat ahli lainnya }
$$
mengemukakan bahwa pengtertian belajar adalah "merupakankan perubahan dalam kepribadian yang dimanifestasikan 
sebagai pola-pola respon yang baru brbentuk keterampilan, sikap; kebiasaan, pengatahuan dan kecakapan" (Witherington, 1983:51). Sedangkan definisi belajar menurut Morgan "Belajar adalah perubahan yang relatif, menetap dalam tingkah laku yang terjadi sebagai suatu hasil dari latihan atau pengalaman" (Depdikbud, 1981:71).

Dari beberapa pengertian dan uraian yang telah dikemukakan di atas, dapat disimpulkan bahwa belajar adalah suatu perubahan tingkah laku yang terjadi relatif menetap sebagai suatu hasil dari latihan atau pengalaman.

Mengajar merupakan istilah kunci yang hampir tak pernah lepas dari pembahasan mengenai pendidikan karena keeratan hubungan antara keduanya. Sebagian orang menganggap mengajar hanya sebagai salah satu alat atau cara dalam menyelenggarakan pendidikan. Konotasinya jelas, mengajar hanya salah satu cara mendidik maka pendidikan dapat berlangsung tanpa pengajaran. Anggapan ini muncul karena adanya asumsi tradisional yang menyatakan bahwa mengajar itu merupakan kegiatan seorang guru yang hanya menumbuh kembangkan ranah cipta siswa-siswanya, sedangkan ranah rasa dan karsa mereka terlupakan.

Dalam menjalankan tugasnya sebagai penyaji pelajaran khususnya di kelas, guru tidak hanya dituntut menstransfer pengetahuan atau isi pelajaran yang ia sajikan kepada siswanya. Sepanjang memungkinkan, guru juga harus menstransfer kecakapan karsa dan kecakapan rasa yang tergantung dalam materi pelajaran yang disajikan. Dengan demikian, mengajar mengandung konotasi membimbing dan membantu untuk memudahkan siswa dalam menjalani proses perubahannya sendiri, yakni proses belajar untuk meraih kecakapan cipta, rasa dan karsa yang menyeluruh dan utuh.

Tugas dan tanggung jawab sebagai pendidik adalah membantu dan membimbing siswa untuk mencapai kedewasaan seluruh ranah kejiwaan sesuai dengan criteria yang telah ditetapkan, baik kriteria institusional maupun konstitusional. Dalam menjalankan tugas dan tanggung jawab tersebut, guru berkewajiban merealisasikan segenap upaya yang mengarah pada pengertian membantu dan membimbing siswa dalam menciptakan 
perubahan positif seluruh ranah kejiwaannya. Dalam hal ini, kegiatan nyata yang paling utama dalam memberikan bantuan dan bimbingan tersebut adalah mengajar.

Pengertian umum yang dipahami orang terutama mereka yang awam dalam bidang-bidang kependidikan menurut Muhibbin Syah (1995:184), adalah bahwa : "mengajar itu merupakan penyampaian pengetahuan dan kebudayaan kepada siswa". Dengan demikian, tujuannyapun hanya berkisar sekitar pencapaian penguasaan siswa atas sejumlah pengetahuan dan kebudayaan. Dari pengertian semacam ini timbul gambaran bahwa peranan dalam proses pengajaran hanya dipegang oleh guru, sedangkan siswa dibiarkan pasif.

Mengajar bukan hanya menyampaikan dan menanamkan pengetahuan dan pandangan kepada anak didik, tetapi juga membimbing anak yang belajar menyesuaikan diri dengan lingkungannya. Menurut I.L Pasaribu dan S. Simandjuntak (1985:7) menyatakan bahwa "mengajar adalah suatu kegiatan mengorganisasi (mengatur) lingkungan sebaik-baiknya dan menghubungkan dengan anak sehingga terjadi proses belajar".

Berdasarkan pendapat ini, mengajar merupakan suatu aktivitas mengorganisasi (mengatur) lingkungan sebaik-baiknya dan menghubungkannya dengan anak sehingga terjadi proses belajar, hal ini berarti bahwa guru hanya menciptakan lingkungan yang mendorong anak untuk belajar sedangkan aktivitas itu datang dari dalam diri anak.

Selanjutnya Muhamad Ali (1987: 12) mengemukakan bahwa : "mengajar adalah suatu upaya dalam rangka kemungkinan baik siswa untuk terjadi proses belajar sesuai dengan tujuan yang telah dirumuskan".

Lingkungan yang dimaksud dari pendapat ini, bukan hanya ruang kelas, (ruang belajar) tetapi juga meliputi guru, alat peraga, perpustakaan, laboratorium, dan sebagainya yang relevan dengan kegiatan belajar siswa.

Disimpulkan bahwa mengajar adalah menciptakan timbulnya prilaku belajar yang menyentuh segenap aspek psikologis siswa. Kedudukan guru tidak hanya sebagai pengusaha tunggal dalam kelas atau sekolah, tetapi sebagai pengelola belajar yang senatiasa 
memberikan bimbingan dan membantu siswa dalam menuju kedewasaan mereka sendiri yang utuh menyeluruh.

Tugas guru yang utama adalah mengajar dan mendidik. Sedangkan kegiatan belajar mengajar merupakan kegiatan sentral dalam tugas sekolah. Dengan demikian seluruh kegiatan sekolah diabdikan untuk kepentingan proses pencapaian tujuan-tujuan pendidik. Kompetensi profesional merupakan syarat pokok dalam meningkatkan produktivitas, efektivitas, efisiensi dan kualitas pendidik.

Dalam bagian ini, terlebih dahulu diuraikan tentang pengertian kompetensi seperti yang terdapat dalam kamus. Menurut Kamus umum Bahasa Indonesia, kompetensi adalah kewenangan, kekuasaan un tuk menentukan atau memutuskan sesuatu hal (Porwandarminta, 1982:518).

Berdasarkan hal ini maka kompetensi guru adalah suatu kewenangan untuk memutuskan suatu hal. Kewenangan dimaksud diperoleh atas dasar spesialisasi sehingga seseorang memiliki penguasaan pengetahuan dan pemahaman terhadap bidang ilmu yang diperlukan untuk menjalankan tugas sebagai guru.

Lebih lanjut mengatakan bahwa : Dalam menghadapi tantangan ini, pembaharuan sistem pendidikan lebihlebih memerlukan ide, ketrampilan, keberanian, determinasi dan kemampuan untuk berubah. Ini berarti bahwa kedudukan eksekutif di dalam hierarki administratif akan harus diisi oleh orang yang berwibawa dan cakap (kompeten). (O. Sutisna, $1987: 4$ ).

Mengajar bukan tugas yang ringan bagi seorang guru, karena dalam mengajar guru berhadapan dengan sekelompok siswa yang memerlukan bimbingan dan pembinaan untuk menuju kedewasaan. Siswa setelah mengalami proses pendidikan dan pengajaran diharapkan telah menjadi manusia dewasa yang sadar dan bertanggung jawab terhadap diri sendiri, berpribadi dan bermoral.

Mengingat tugas yang berat tersebut, guru yang mengajar di depan kelas harus menguasai dengan baik berbagai teknik dan ketrampilan dalam pengajaran yang merupakan serangkaian kegiatan yang harus dilakukan guru dalam proses belajar mengajar di kelas. 
Adapun ketrampilan-ketrampilan yang perlu dimiliki guru tersebut menurut Nasution. S (1994: 171-187) antara lain :

\section{Keterampilan Membuka dan Menutup} Pelajaran

Pengertian yang dimaksud dengan membuka pelajaran adalah kegiatan yang dilakukan oleh guru untuk menciptakan suasana siap mental dan menimbulkan perhatian siswa agar terpusat pada hal-hal yang akan dipelajari. Untuk menciptakan suasana siap mental tersebut guru melakukan usaha-usaha memberi acuan dan membuat kaitan antara materi pelajaran yang telah dikuasai siswa dengan bahan baru yang akan dipelajari.

Siswa yang siap mental untuk belajar adalah mereka yang telah mengetahui :

- Tujuan pelajaran

- Masalah-masalah pokok yang harus diperhatikan

- Langkah-langkah kegiatan belajar yang akan dilakukan

- Mengetahui batas-batas tugas yang harus dikerjakan untuk menguasai pelajaran tersebut.

Untuk menimbulkan perhatian dan memotivasi siswa terhadap hal-hal yang dipelajari, guru dapat menimbulkan rasa ingin tahu, sikap hangat dan antusias, memberikan variasi mengajar. Siswa yang telah termotivasi dan penuh perhatian, akan melaksanakan tugas dengan penuh gairah, semangat tinggi, cepat bereaksi terhadap pertanyaanpertanyaan guru.

Sedangkan yang dimaksud dengan menutup pelajaran adalah kegiatan yang dilakukan guru untuk mengakhiri kegiatan inti pelajaran. Usaha menutup pelajaran tersebut dimaksud untuk memberikan gambaran menyeluruh tentang apa yang dipelajarai siswa, mengetahui tingkat pencapaian siswa dan tingkat keberhasilan guru dalam proses belajar mengajar. Usaha-usaha yang dapat dilakukan guru antara lain merangkum kembali atau menyuruh siswa membuat ringkasan dan mengadakan evaluasi tentang materi pelajaran yang baru saja diberikan.

Penggunaan ketrampilan membuka dan menutup pelajaran sangat erat hubungannya dengan tujuan sebagai berikut :

- Menumbuhkan perhatian dan memotivasi siswa dalam menghadapi tugas yang akan dikerjakan. 
- Menyadarkan siswa akan batas-batas tugas yang akan dikerjakan.

- Memberikan gambaran yang jelas tentang langkah-langkah yang dapat digunakan untuk mempelajari bagianbagian dari pelajaran yang akan diberikan.

- Menunjukan hubungan antara pengalaman-pengalaman yang telah dikuasai dengan hal-hal baru yang akan dipelajari.

- Mengajak siswa untuk dapat menggabungkan fakta-fakta, ketrampilan atau konsep-konsep yang tercakup dalam suatu peristiwa.

- Menunjukan tingkat keberhasilan siswa dalam mempelajari sesuatu, juga tingkat keberhasilan guru dalam mengajar.

Usaha menutup pelajaran tersebut dimaksud untuk memberikan gambaran menyeluruh tentang apa yang dipelajari siswa, mengetahui tingkat pencapaian siswa dan tingkat keberhasilan guru dalam proses belajar mengajar yang dilakukan melalui kegiatan evaluasi dalam setiap selesai penyampaian materi pokok bahasan. a. Prinsip-prinsip penggunaan membuka dan menutup pelajaran Prinsip-prinsip yang perlu diperhatikan oleh guru adalah :

- Bermakna

Usaha untuk menarik perhatian dan memotivasi siswa hendaknya berkaitan dengan materi serta tujuan pelajaran, sehingga hal-hal yang tidak berkaitan seperti lawakan atau cerita lain dihindarkan.

- Berurutan dan berkesinambungan Usaha yang dilakukan guru baik dalam memperkenalkan materi maupun merangkum pokok-pokok penting yang telah diajarkan, hendaknya merupakan satu kesatuan yang berurutan serta berkesinambungan.

b. Komponen-komponen membuka pelajaran

Kegiatan membuka pelajaran biasanya dilakukan pada awal suatu jam pelajaran dan pada awal setiap penggal pelajaran untuk membawa siap mental menghadapi pelajaran. Adapun komponen-komponenya adalah :

1) Menarik perhatian siswa 
Untuk menarik perhatian siswa dapat dilakukan hal-hal sebagai berikut :

- Gaya mengajar guru

Berbagai variasi gerak atau posisi guru, kontak pandang atau suara guru, penggunaan pause atau komentar yang jelas dapat menarik perhatian siswa.

- Penggunaan berbagai media

Untuk menarik perhatian siswa, guru dapat menggunakan berbagai jenis media yang berkaitan dengan materi yang diajarkan, misalnya menggunakan gambar disertai model atau benda yang sebenarnya.

- Perubahan pola interaksi gurusiswa

Pola interaksi guru-siswa, dimana guru berbicara sedangkan siswa mendengarkannya, hanya menimbulkan sistimulus awal saja. Perhatian siswa belum sepenuhnya terpusat pada pokok pelajaran yang akan dipelajari. Oleh karena itu, agar siswa tertarik pada hal-hal yang akan diberikan, guru harus membuat berbagai variasi pola interaksi. Misalnya guru bertanya, siswa menjawab, kemudian siswa lain memberikan tanggapan, yang dilanjuti dengan komentar atau tambahan dari siswa lainnya, sehingga pola interaksi tidak hanya guru-siswa melainkan gurusiswa, siswa-siswi, siswa-guru dan sebagainya.

2) Menimbulkan motivasi

Kegiatan yang berhubungan erat dengan prosedur membuka pelajaran adalah memilih hal-hal yang menjadi perhatian siswa yang dapat digunakan untuk menimbulkan motivasi.

3) Memberi acuan

Memberi acuan merupakan suatu komentar guru untuk memasuki suatu pelajaran, terutama antara pengetahuan yang baru dengan apa yang sudah dipelajari siswa.

4) Membuat kaitan

Untuk mempermudah pemahaman siswa terhadap hal-hal baru yang akan diajarkan, guru perlu menghubungkan hal-hal yang telah dipelajari atau pengalamanpengalaman siswa terdahulu sebagai bahan pengait. 
c. Komponen-komponen menutup
pelajaran

Seperti halnya dengan membuka pelajaran, demikian pula menutup pelajaran tidak hanya dilakukan menjelang akhir pelajaran, tetapi juga pada akhir setiap penggalan kegiatan, dengan maksud memperoleh gambaran yang utuh tentang pokok-pokok materi yang dipelajari. Cara-cara yang dapat dilakukan adalah :

- Meninjau kembali

Tiap akhir suatu jam pelajaran, guru meninjau kembali, apakah inti pelajaran yang diajarkan itu telah dikuasaisiswa.

- Mengevaluasi

Salah satu cara untuk mengetahui, apakah siswa telah memperoleh gambaran yang utuh tentang konsep yang telah diajarkan adalah dengan penilaian, yang dapat dilaksanakan guru dengan memberikan pertanyaanpertanyaan atau tugas-tugas.

2. Keterampilan Menjelaskan

Menuntut mengajar merupakan suatu kegiatan yang sangat komplek. Hal ini disebabkan kegiatan mengajar menuntut profesionalisme yang tinggi dan merupakan aplikasi ilmu pengetahuan serta teknologi secara terampil oleh seorang guru dalam upaya merubah tingkah laku peserta didik untuk mencapai tingkah laku yang diinginkan dalam tujuan pembelajaran. Untuk mencapai hal tersebut maka perlu diperhatikan aspek-aspek sebagai berikut

a. Faktor persiapan/perencanaan guru

Persiapan materi guru dalam mengajar harus direncanakan dan dibuat dalam bentuk silabus, rencana pelaksana pembelajaran, dan satuan pelajaran sesuai dengan tingkat pendidikan tersebut.

b. Faktor siswa (penerima pelajaran)

Dalam memberikan pelajaran guru perlu memperhatikan kesiapan siswa penerima penjelasan., karena keberhasilan suatu penjelasan sangat tergantung dengan kesiapan siswa yang menerima materi pelajaran. Kesiapan ini berkaitan dengan usia, kemampuan, latar belakang, dan lingkungan belajar. Beberapa aspek yang harus diperhatikan dalam ketrampilan menjelaskan antara lain yaitu : Bahasa /istilah yang digunakan, pendukung penjelasan (contoh/ilustrasi), 
umpan balik dari siswa dan kesimpulan dari guru.

\section{Keterampilan Bertanya}

Dalam proses pembelajaran tujuan pertanyaan yang diajukan guru adalah agar siswa belajar, yaitu memperoleh pengetahuan dan meningkatkan kemampuan berfikir siswa. Penguasaan ketrampilan bertanya yang efektif dan efisien bagi seorang sangat penting agar kegiatan belajar siswa lebih banyak berinteraksi dan berpartisipasi dalam bentuk bertanya, menjawab, dan mengajukan pendapat. Fungsi pertanyaan guru adalah sebagai alat mengajar. Tujuan yang ingin dicapai dari pertanyaan guru yang diajukan kepada siswa yaitu : untuk memusatkan perhatian, membangkitkan minat, dan rasa ingin tahu siswa terhadap suatu pokok bahasan, mendiagnosis kesulitan-kesulitan khusus yang menghambat siswa belajar, mendorong siswa mengemukakan pandangannya dalam diskusi, menguji dan mengukur hasil belajar siswa dalam melaksanakan tugas.

4. Keterampilan Mengadakan Variasi

$\begin{array}{lcr}\text { Variasi } & \text { dalam } & \text { kegiatan } \\ \text { pembelajaran } & \text { dimaksudkan } & \text { sebagai } \\ \text { proses perubahan dalam pengajaran yang }\end{array}$

berguna untuk mengurangi rasa kebosanan dalam menerima pelajaran. Manfaat mengadakan variasi dalam mengajar terutama untuk pemusatan perhatian dan pemberian motivasi serta berguna untuk meningkatkan perhatian siswa kepada aspek-aspek pembelajaran yang relevan, memupuk tingkah laku positif terhadap guru dan sekolah dengan berbagai cara mengajar yang lebih hidup dan lingkungan belajar yang lebih baik, memberi kesempatan siswa mendapatkan cara menerima pelajaran yang disenanginya, dan meningkatkan cara belajar siswa aktif dalam brbagai pengalaman yang menarik dan terarah pada berbagai tingkat kognitif (pengetahuan).

\section{Ketrampilan Mengelola Kelas}

Suatu kondisi belajar yang kondusif dapat tercapai apabila guru mampu memanajemen, menggunakan sarana pembelajaran, mengatur siswa, dan mengendalikannya di dalam kondisi disiplin dalam suasana yang menyenangkan untuk mencapai tujuan pembelajaran. Pengelolaan kelas yang berhasil memungkinkan timbul dan terpeliharanya disiplin. Disiplin yang efektif bercirikan adanya keterlibatan 
guru dan siswa secara penuh dalam tugas kelas sehingga tercipta iklim yang bebas gangguan dari tingkah laku siswa yang tidak diinginkan.

Untuk dapat mengelola kelas dengan efektif seorang guru perlu mengembangkan pola kepemimpinan yang efektif, memiliki kekuatan sosial sehingga siswa merasa nyaman, keserasian baik terhadap guru maupun terhadap sesama siswa.

6. Ketrampilan memberi penguatan

Penguatan adalah segala bentuk respons terhadap suatu tingkah laku yang dapat meningkatkan kemungkinan berulangnya kembali tingkah laku tersebut.

Tujuan pemberian penguatan mempunyai pengaruh yang positif terhadap proses belajar siswa dan bertujuan sebagai :

- Meningkatkan perhatian siswa terhadap pelajaran

- Merangsang dan meningkatkan motivasi belajar

- Meningkatkan kegiatan belajar dan membina tingkah laku siswa yang produktif.

7. Ketrampilan membimbing diskusi kelompok kecil
Diskusi kelompok adalah suatu proses yang teratur yang melibatkan sekelompok orang dalam interaksi tatap muka yang informal dengan berbagai pengalaman atau informasi. Diskusi kelompok yang efektif harus didahului dengan perencanaan dan persiapan yang matang. Adapun langkah-langkah yang dilakukan dalam pelaksanaan membimbing diskusi kelompok sebagai berikut :

a) Memilih topik atau masalah yang akan didiskusi

Untuk pemilihan topik, guru harus mempertimbangkan minat, kemampuan serta jenis topik yang bermakna bagi siswa.

b) Menyiapkan berbagai informasi yang dapat menunjang kelancaran jalannya diskusi.

Informasi yang dimaksud adalah berwujud buku-buku, hasil penelitian, observasi atau bahan-bahan lain, selain guru sendiri sebagai nara sumber.

c) Menetapkan jumlah anggota dan tempat duduk.

Jumlah anggota tidak ada keharusan mutlak, tergantung berbagai faktor seperti : pengalaman, kematangan, ketrampilan anggota, pengetahuan 
anggota terhadap topik, tingkat kekompakan serta kepemimpinan guru. Sedangkan tempat duduk diatur sedemikian rupa sehingga memungkinkan setiap anggota dapat bertatap muka secara langsung dengan anggota yang lain menggunakan pendapat.

8. Ketrampilan mengajar perorangan

Secara fisik bentuk pengajaran ini jumlah siswa yang dihadapi oleh guru terbatas, berkisar antara 3-8 orang untuk kelompok kecil, dan seorang untuk perseorangan. Langkah-langkah ketrampilan mengajar perorangan sebagai berikut :

a. Bagi guru yang sudah biasa dengan pengajaran klasikal, sebaiknya dimulai dengan pengajaran kelompok, kemudian secara bertahap mengarah kepada pengajaran perseorangan.

b. Tidak setiap topik dapat dipelajari secara kelompok ataupun perorangan, artinya perlu penjelasan secara umum dalam bentuk pengajaran klasikal

c. Perlu adanya pengorganisasi siswa, materi, sumber, ruangan, dan waktu yang diperlukan. d. Kegiatan pengajaran perorangan yang efektif hendaknya diakhiri dengan rangkuman, laporan dan pemantapan.

e. dalam pengajaran perorangan sangat diperlukan pengenalan siswa secara pribadi

f. Kegiatan perorangan dapat diarahkan dengan tugas terstruktur, kerja bebas dan terjadwal.

Secara umum prestasi merupakan hasil yang dicapai seseorang ketika mengerjakan tugas stau kegiatan tertentu. Sementara prestasi belajar adalah penguasaan pengetahuan atau keterampilan yang dikembangkan melalui mata palajaran, yang lazimnya ditujukan dengan nilai test atau angka yang diberikan oleh guru.

Menurut Tulus (2004:275), prestasi belajar siswa dapat dirumuskan sebagai berikut :

1. Prestasi belajar siswa adalah hasil belajar yang dicapai siswa ketika mengikuti dan mengerjakan tugas dan kegiatan pembelajaran di sekolah.

2. Prestasi belajar siswa tersebut teritama dinilai dari aspek kognitifnya karena bersangkutan dengan kemampuan siswa dalam pengetahuan atau ingatan, 
pemahaman, aplikasi, analisis, sintesa dan evaluasi.

3. prestasi belajar siswa dibiktikan dan ditujukan melalui nilai atau angka, nilai dari evaluasi yang dilakukan oleh guru terhadap tugas siswa dan ulangan-ulangan atau ujian yang ditempuh. Hasil evaluasi tersebut didokumentasikan dalam buku daftar guru dan wali kelas serta arsip yang ada di bagian administrasi kurikulum sekolah.

Berdasarkan uraian di atas, dapat dipertegas bahwa prestasi belajar adalah tingkat penguasaan materi pelajaran yang mempunyai suatu kemajuan dan kematangan yang dicapai oleh siswa setelah melewati proses belajar. Dan prestasi belajar merupakan tingkat keberhasilan siswa dalam penguasaan mata pelajaran yang telah diberikan oleh guru, yang mana setelah melalui proses evaluasi atau test (ujian) siswa tersebut mendapat nilai yang tinggi. Jadi prestasi belajar merupakan gambaran kemampuan seseorang menguasai pengetahuan dan keterampilan yang dikembangkan oleh suatu ilmu pengetahuan dengan angka/nilai pemberian guru.

\section{PENUTUP}

Kegiatan pengelolaan melalui unsur siswa, sarana pembelajaran dan kondisi lingkungan belajar (kelas) yang baik. Pengelolaan pembelajaran adalah merupakan usaha untuk menciptakan suasana fisik maupun mental yang optimal sebagai kondisi untuk siap terlibat dalam kegiatan/proses pembelajaran sehingga menghasilkan perubahan sikap atau tingkah laku sesuai tujuan khusus pembelajaran. Suatu kondisi pembelajaran yang kondusif (mendukung) dapat dicapai apabila guru mampu memanajemen, menggunakan sarana pembelajaran, dan mengatur siswa serta mengendalikannya di dalam suatu kondisi disiplin suasana yang menyenangkan untuk mencapai tujuan pembelajaran. Pengaturan siswa belajar di sekolah dilakukan sedemikian rupa sehingga siswa mendapat pelayanan menurut kebutuhannya dan mendapat hasil pendidikan yang maksimal secara efektif dan efisien. Pengelolaan sarana pembelajaran yang dilakukan oleh guru meliputi : mengorganisasi materi pelajaran, menentukan struktur pelajaran, penggunaan media pengajaran, dan penyajian materi pelajaran. Sedangkan 
kegiatan pengelolaan kelas adalah pengaturan siswa di kelas oleh guru yang sedang mengajar sehingga setiap siswa mendapat pelayanan sesuai dengan kebutuhannya.

Kegiatan pengelolaan secara keseluruhan dalam pembelajaran merupakan pelaksanaan dari unsur-unsur yang terdapat dalam perencanaan pembelajaran yang telah disusun sebelumnya. Kegiatan pengelolaan pembelajaran secara baik melalui dari kegiatan perencanaan, pelaksanaan hingga tindaklanjutnya merupakan tugas guru yang harus dilakukannya. Namun demikian, bimbingan dan pengawasan yang efektif masih sangat dibutuhkan. Peran kepala sekolah sangat menentukan dalam menciptakan suasana lembaga yang baik, kegiatan pembelajaran yang berlangsung secara kondusif dalam sekolah akan menunjang pencapaian tujuan pendidikan. Kontrol penhawasan kepala sekolah sangat penting dalam memelihara dan meningkatkan semangat kinerja (kerja) guru. Berkaitan dengan keterlaksanaan fungsi pembelajaran, masih ada para guru yang enggan mengelolanya dengan baik mulai dari kegiatan perencanaan, pelaksanaan, dan tindak lnjut. Hal ini sering terjadi karena tidak adanya perhatian khusus dari kepala sekolah. Mengenai hal ini Nanang Fattah (2000:106-107) menyatakan bahwa : Pengawasan sebagai kontrol kualitas akan dapat efektif jika pada setiap tingkatan pendidikan mempunyai keterpaduaan, kerja sama yang baik antara kelompok kerja (guru) dan pimpinan dalam melakukan pengawasan mutu.

Lebih lanjut juga dikemukakan bahwa beberapa kondisi yang harus diperhatikan agar pengawasan efektif, antara lain :

1. Pengawasan harus dikaitkan dengan tujuan, dengan criteria : relevansi, efektifitas, efesiensi dan produktivitas.

2. Standar yang ingin dicapai harus ditentukan terlebih dahulu.

3. banyaknya pengawasan harus dibatasi.

4. Sistem pengawasan harus dikemudi tanpa mengorbankan otonomi dan kehormatan manajerial tetapi fleksibel.

5. Pengawasan hendaknya mengacu pada tindakan perbaikan.

6. Pengawasan hendaknya mengacu pada prosedur pemecahan masalah.

Dengan demikian maka pengelolaan dalam proses pembelajaran merupakan hal yang sangat penting dalam 
upaya mencapai suatu tujuan yang telah ditiapkan.

\section{DAFTAR PUSTAKA}

Bahridjamarah, Saiful dan Aswan Zain. 2002. Strategi Belajar Mengajar. Jakarta : Rineka Cipta.

Departemen Pendidikan dan Kebudayaan. 1991. Kamus Besar Bahasa Indonesia, Edisi kedua, Balai Pustaka.

Kajeng, I Nyoman, dkk. 1997. Sarasamuccaya. Surabaya : Paramita.

Mantra, I Bagus. 2003. Bhagawadgita Alih bahasa dan Penjelasan, Proyek Peningkatan Koordinasi Terhadap Umat Hindu di Luar Daerah, Denpasar.

Majelis Besar Alim Ulama Kaharingan Indonesia. 1996. Panaturan, Palangka Raya.

Ngurah, I Gusti Made, 1989. Pedoman Guru Pendidikan Agama Hindu, Widya Dharma, Denpasar.

Pudja,G. 2003. Bhagawad-Gita (Pancama Weda). Jakarta : Pustaka Mitra.

Tim Penyusun. 1997. Pendidikan Agama Hindu Untuk Perguruan Tinggi. Jakarta : Hanuman Sakti.

Tim Penyusun. 1994. Penuntun Belajar Agama Hindu I. Bandung : Ganeca Exact.

Tim Penyusun. 2006. Buku Pelajaran Agama Hindu Untuk Kelas VII. Denpasar: Widyadharma.

Tim Penyusun. 2006. Buku Pelajaran Agama Hindu Untuk Kelas VIII. Denpasar : Widyadharma.
Tim Penyusun. 2006. Buku Pelajaran Agama Hindu Untuk Kelas IX. Denpasar : Widyadharma.

Tim Penyusun. 2003. Undang-Undang Republik Indonesia No.20 Tahun 2003 Tentang Sistem Pendidikan Nasional. Semarang : CV. Aneka Ilmu.

Titib, I 2003. Menumbuhkembangkan Pendidikan Budhi pekerti pada Anak. Jakarta PHDI Pusat.

Winata Putra, H. Udin S, dkk. 2003. Pedoman Umum Pendidikan Budhi Pekerti Pada Jenjang Sekolah Dasar dan Menengah. Jakarta : Ditjen Diknasmen. 